\title{
Mechanical properties of Rowan wood impregnated with various chemical materials
}

\author{
Hakan Keskin ${ }^{1}$, Neslihan Süzer Ertürk², Mustafa Hilmi Çolakoğlu ${ }^{3}$ and Süleyman Korkut ${ }^{4 *}$ \\ ${ }^{1}$ Department of Woodworking Industry Engineering, Faculty of Technology, Gazi University, 06500 Beşevler, \\ Ankara, Turkey. \\ ${ }^{2}$ Department of Industrial Technology, Faculty of Industrial Arts Education, Gazi University, 06830 Gölbaşi, \\ Ankara, Turkey. \\ ${ }^{3}$ Technology Development Foundation of Turkey (TTGV) 06800 Bilkent, Ankara, Turkey. \\ ${ }^{4}$ Department of Forest Industrial Engineering, Faculty of Forestry, Düzce University, 81620 Düzce, Turkey.
}

Accepted 2 January, 2013

\begin{abstract}
The aim of this research was to determine some of the mechanical properties of Rowan wood impregnated with various impregnation materials. For this purpose, the test samples were prepared from Rowan (Sorbus aucuparia Lipsky) wood materials that are of common use in the forest products industry of Turkey according to TS 345 . The test samples were treated with Tanalith-E, Vacsol Azure, Imersol-Aqua, and Boron compounds (Borax and Boric acid) by the vacuum impregnation technique in accordance with ASTM-D 1413-76 standards and directives of the manufacturers. After impregnation, each sample was tested for observation of amount of retention, compression strengths, bending strengths, and modulus of elasticity in bending. As a result, compression strength was the highest with Boric acid impregnation, bending strength with Imersol-Aqua impregnation and modulus of elasticity in bending with Tanalith-E impregnation. The lowest value in compression strength was measured with Tanalith-E, bending strength in Borax and modulus of elasticity in bending with Vacsol Azure. So, the impregnations with Tanalith-E have advantages in compression and bending strengths and modulus of elasticity in bending of Rowan wood.
\end{abstract}

Key words: Rowan wood, chemical materials, compression strength, bending strength, modulus of elasticity in bending.

\section{INTRODUCTION}

The durability of wood is affected by several factors. If the wood materials are used without processing by preservative chemicals (with regard to the area of usage), fungal stains, insect infestation, humidity, fire etc damage the wood. As a result of these damages, the woods require to be repaired, maintained or replaced before its economic life ends (Richardson, 1987). For this reason, in most places the wood materials should be impregnated with the proper chemicals. In the case of the wood not been impregnated but only painted and varnished instead, the prevention on the surfaces is limited to a maximum of two years (Evans et al., 1992).

\footnotetext{
${ }^{*}$ Corresponding author. E-mail: suleymankorkut@hotmail.com.
}

It is reported that, in mines, as a result of the impregnation of the beech and spruce wood with watersoluble salts, the bending, tensile, and impact strength decreased a little whereas compression strength increased (Kollmann, 1959). In another research concerning the impregnation of pine, spruce, fir, beech, and poplar woods with Antrasen, it was found that, the compression strength increased by 6 to $40 \%$ and bending strength increased by 10 to $22 \%$ (Stabnikov, 1957). In the impregnation of pine and beech wood with tar oil and UA salts, the tar oil increased compression strength by $10 \%$ and UA salts increased with a small rate. On the other hand, the tar oil increased the bending strength whereas the UA salts diminished the bending strength (Gillwald, 1961).

Vologdin (1966) declared that, among the materials 
used for the impregnation of pine; sodium pentaclorfenet, copper sulphate, and sodium fluoride increased the compression strength, respectively by 95,25 , and $3 \%$ whereas zinc chloride decreased by $9 \%$. Sodium pentaclorfenet also increased the bending strength. In another study, pressure treatment caused a decrease of 8 to $10 \%$ in the bending strength of different wood types (Isaacs, 1972). It was assessed that, salty impregnation materials increased the compression strength by 4.6 to $9.6 \%$, whereas decreased the bending strength by 2.9 to $16 \%$ (Wazny, 1973). In another study, chromate copper arsenate (CCA) and arsenate copper arsenate (ACA) salts did not caused any significant impact on modulus of elasticity in bending (Bendtsen, 1984).

After the impregnation of Scotch pine wood samples by hot-cold open tank method with eleven preservatives, no significant difference was observed in the bending strength except the decreasing effects of fluotox containing acid florid (Lutomsky, 1976).

Korkut et al. (2009) determined Rowan wood's air dry $\left(801 \mathrm{~kg} / \mathrm{m}^{3}\right)$, oven dry $\left(737 \mathrm{~kg} / \mathrm{m}^{3}\right)$ and basic $\left(635 \mathrm{~kg} / \mathrm{m}^{3}\right)$ densities. Fiber saturation point was calculated to be $23.79 \%$; volumetric shrinkage and swelling were found as 15.048 and $18.465 \%$; bending strength (MOR), modulus of elasticity (MOE), compression strength parallel to grain, impact bending, tensile strength parallel and perpendicular to grain, shear strength, cleavage strength, Janka hardness values (parallel and perpendicular to grain) and surface roughness $(\mathrm{Ra})$ value were determined as $115.571 \mathrm{~N} / \mathrm{mm}^{2}, 9843.857 \mathrm{~N} / \mathrm{mm}^{2}, 55.027$ $\mathrm{N} / \mathrm{mm}^{2}, 14.849 \mathrm{~J} / \mathrm{cm}^{2}, 120.71 \mathrm{~N} / \mathrm{mm}^{2}, 6.187 \mathrm{~N} / \mathrm{mm}^{2}$, $12.792 \mathrm{~N} / \mathrm{mm}^{2}, 0.941 \mathrm{~N} / \mathrm{mm}^{2}, 1.416$ and $1.159 \mathrm{kN}, 7.239$ $\mu \mathrm{m}$, respectively.

Özçifci et al. (1999) carried out a research on yellow pine, oriental beech, ash-tree, and oak woods bleached with $\mathrm{NaOH}+\mathrm{H}_{2} \mathrm{O}, \mathrm{NaOH}+\mathrm{Ca}(\mathrm{OH})_{2}+\mathrm{H}_{2} \mathrm{O}_{2}, \mathrm{HClO}$, and $\mathrm{HCl}$ and varnished with synthetic, polyurethane, acid catalytic varnish to research the impact on surface adhesion strength and brightness. These chemicals have no impact on brightness: Wood type and varnish type was important for brightness. The highest brightness of surface was determined with acrylic varnish and the lowest with acid hardened varnish. $\mathrm{HCl}$ decreases adhesion strength of varnishes. Uysal et al. (1999) studied static bending strength of yellow pine, oriental beech, ash-tree and oak woods bleached with $\mathrm{NaOH}+\mathrm{H}_{2} \mathrm{O}_{2}, \mathrm{NaOH}+\mathrm{Ca}(\mathrm{OH})_{2}+\mathrm{H}_{2} \mathrm{O}_{2}, \mathrm{HClO}$ and $\mathrm{HCl}$ : They determined that $\mathrm{HClO}$ and $\mathrm{HCl}$ causes the highest decrease in bending strength.

Aytaşkin (2009) studied the impact of impregnation materials on wood types and determined that the impregnation materials increase the density and heat conduction of woods. Impregnation materials also have impacts on the mechanical properties, decreases the bending strength and modulus of elasticity. Compression strength and impregnation relation depends on the type of impregnation material. Impregnation materials decrease the adhesion strength of woods and also the weight loss in combustion tests. Kartal (1998) determined that, impregnation with CCA and drying at a temperature $70^{\circ} \mathrm{C}$ for $72 \mathrm{~h}$ have no impact on the mechanical properties of wood, but the differences between the control samples in bending test with fixation at 20 and $70^{\circ} \mathrm{C}$ was statistically meaningful at level of $5 \%$.

One well-known technique to protect wood is by impregnating it with chemical products. In this study, naturally growing in Turkey, thin in texture, flexible and hard Rowan wood (Sorbus aucuparia Lipsky) was impregnated with Tanalith-E, Imersol Aqua, Vacsol Azure, and Boron compounds and tested in retention, compression strength, bending strength, and modulus of elasticity in bending.

\section{MATERIALS AND METHODS}

\section{Wood materials}

Test samples were obtained from Kastamonu Forestry Regional Directory, Küre Directory, Kösreli Department number 200. Test samples were cut from the trees in accordance with TS 4176 (1984) standard. Test samples were prepared in accordance with TS 2470 (1976) and TS 53 (1981). Accordingly, non-deficient, knotless, normally growth (without zone line, without reaction wood and without decay and insect mushroom damage) wood materials was selected. Test samples cut to $70 \times 70 \times 800 \mathrm{~mm}$ were air-dried at a temperature of $20 \pm 2{ }^{\circ} \mathrm{C}$ and $65 \pm 3 \%$ relative humidity conditions up to reaching $12 \%$ humidity level.

\section{Impregnation material}

\section{Tanalith-E}

Tanalith-E is an impregnation material used against the attacks of agent, yeast, insect, and termite. It is a new generation of impregnation material consisting of copper and organic biocide (triazole) and not harmful to plant, animal, and human health. Tanalith-E, light green in color, odorless, $\mathrm{pH} \mathrm{7,} \mathrm{1:04} \mathrm{g/cmP} \mathrm{cm}^{3}$ density, smooth and completely water-soluble, water-based, non-corrosive to metal parts are available in the form of ready solution. Tanalith- $E$ was applied to woods used in fences, railings, garden furniture, barns, silos, farm buildings, the wood used in children's play areas by vacuum - pressure method (Hickson's Timber Impregnation Co. (GB), 2000).

\section{Vacsol Azure}

Vacsol Azure a product of a new technology developed by using active ingredients, used in the process, ground wood materials on the level of fungi, insects (Propiconazole and tebuconazole), and termites (permethrin) to prevent decay by protecting against transparent impregnating agent. This solvent-based material is water-insoluble, pale yellow in color, flammable, density 0.806 $\mathrm{g} / \mathrm{cm} 3$ at $20 \pm 2{ }^{\circ} \mathrm{C}$, contains $64 \%$ of volatile organic compounds (VOC) (Hickson's Timber Impregnation Co. (GB), 2000).

\section{Imersol-Aqua}

Imersol-Agua, used as an impregnation material in this study was supplied from Hemel (Hemel-Hickson Timber Products Limited), Istanbul. Imersol-Aqua is non-flammable, odorless, fluent, water- 
based and completely soluble in water and non-corrosive material with a $\mathrm{pH}$ value of 7 and a density of $1.03 \mathrm{~g} \mathrm{~cm}^{-3}$. It is available as a ready-made solution. It contains $0.5 \% \mathrm{w} / \mathrm{w}$ tebuconazole, $0.5 \% \mathrm{w} / \mathrm{w}$ propiconazole, $1 \% \mathrm{w} / \mathrm{w}$ 3-lodo-2-propynl-butyl carbonate, and 0.5\% $\mathrm{w} / \mathrm{w}$ cypermethrin. Before the application of Imersol-Aqua on the wood material, all kinds of drilling, cutting, turning, and milling operations should be completed and the relative humidity should be in equilibrium with the test environment. In the impregnation process, dipping duration should be at least $6 \mathrm{~min}$ and the impregnation pool must contain at least 15 liters of impregnation material for $1 \mathrm{~m}^{3}$ of wood. The impregnated wood should be left for drying for at least $24 \mathrm{~h}$ at $20 \pm 2{ }^{\circ} \mathrm{C}$ and $65 \% \pm 3$ (Hickson's Timber Impregnation Co. (GB), 2000).

\section{Determination of density}

The densities of wood materials, used for the preparation of test samples were determined according to TS 2472 (1976). For determining the air-dry density, the test samples with a dimension of $20 \times 30 \times 30 \mathrm{~mm}$ were kept under the conditions of temperature at $20 \pm 2{ }^{\circ} \mathrm{C}$ and $65 \pm 3 \%$ relative humidity until they reached to a stable weight. The weights were measured with an analytic scale of $\pm 0.01 \mathrm{~g}$ sensitivity. Afterwards, the dimensions were measured with a digital compass of $\pm 0.01 \mathrm{~mm}$ sensitivity. The air-dried densities $\left(\delta_{12}\right)$ of the samples were calculated by the formula:

$\delta_{12}=\frac{W_{12}}{V_{12}} \mathrm{gcm}^{-3}$

Where, $W_{12}$ is the air-dry weight $(\mathrm{g})$ and $V_{12}$ is the air-dry volume $\left(\mathrm{cm}^{3}\right)$.

The samples were kept at a temperature of $103 \pm 2^{\circ} \mathrm{C}$ in the drying oven until they reached to a stable weight for the assessment of full dry density. Afterwards, the full dried samples were cooled in the desiccators containing phosphorus pentoxide $\left(\mathrm{P}_{2}\right.$ $\mathrm{O}_{5}$ ). Then, they were weighted on a scale of $\pm 0.01 \mathrm{~g}$ sensitivity and their dimensions were measured with a digital compass of \pm $0.01 \mathrm{~mm}$ sensitivity. The volumes of the samples were determined by stereo metric method and the densities $(\delta 0)$ were calculated by the formula:

$\delta o=\frac{W o}{V o} \mathrm{gcm}^{-3}$

Where, Wo is the full dry weight $(\mathrm{g})$ and $V o$ is the full dry volume $\left(\mathrm{cm}^{3}\right)$.

\section{Determination of humidity}

The humidity of test samples before and after the impregnation process was determined according to TS 2471 (1976). Thus, the samples with a dimension of $20 \times 20 \times 20 \mathrm{~mm}$ were weighed and then oven dried at $103 \pm 2^{\circ} \mathrm{C}$ till they reach to a constant weight. Then, the samples were cooled in desiccators containing phosphorus pentoxide $\left(\mathrm{P}_{2} \mathrm{O}_{5}\right)$ and weighed with an analytic scale of $0.01 \mathrm{~g}$ sensitivity. The humidity of the samples $(r)$ was calculated by the formula;

$r=\frac{M r-M o}{M o} \times 100$

Where, $M r$ is the initial weight $(\mathrm{g})$ and $M o$ is the full-dry weight $(\mathrm{g})$.

\section{Preparation of the test samples}

The rough drafts for the preparation test and control samples were cut from the sapwood parts of massive woods and conditioned at a temperature of $20 \pm 2{ }^{\circ} \mathrm{C}$ and $65 \pm 3 \%$ relative humidity for three months until reaching an equilibrium in humidity distribution. The samples for compression strength test, with a dimension of $20 \times 20$ $\times 30 \mathrm{~mm}$ were cut from the drafts having an average humidity of 12\% according to TS 2595 (1977). The samples for bending strength and modulus of elasticity in bending test, with a dimension of $20 \times 20 \times 400 \mathrm{~mm}$ were cut from the drafts having an average humidity of $12 \%$ according to TS EN 408 (2011). The densities and humidity values of all test samples were measured before the impregnation process.

The test samples were impregnated according to ASTM-D 141376 (1976), TS 344 (2012) and TS 345 (2012). Accordingly, test samples were subject to $60 \mathrm{~cm} \mathrm{HgP}^{-1 P}$ (vacuum) for 60 min and to diffusion at normal atmospheric pressure. Impregnated test samples were air-dried and then, weighed with $0.001 \mathrm{~g}$ precision analytical balance and retention amount were calculated. The processes were carried out at $20 \pm 2^{\circ} \mathrm{C}$. Retention of impregnation material $(R)$ was calculated by the formula:

$R=\frac{G \cdot C}{V} 10^{3} \mathrm{~kg} \mathrm{~m}^{-3} \quad G=T_{2}-T_{1}$

Where, $G$ is the amount of impregnation solution absorbed by the sample $(\mathrm{g}), T_{2}$ is the sample weight after the impregnation $(\mathrm{g}), T_{1}$ is the sample weight before the impregnation $(\mathrm{g}), C$ is the concentration (\%) of the impregnation solution and $V$ is the volume of the samples $\left(\mathrm{cm}^{3}\right)$.

Impregnated test samples were kept under a temperature of $20 \pm$ $2{ }^{\circ} \mathrm{C}$ and $65 \pm 3 \%$ relative humidity until they reach a stable weight. Five types of impregnation materials (Tanalith-E, Imersol Aqua, Vacsol Azure, Boric acid and Borax), four test types (retention amount, compressive strength, flexural strength and modulus of elasticity) plus one control and ten replications for a total of 250 test samples were prepared.

\section{Compression strength}

The tests for compression strength parallel to grains of wood materials were carried out with Universal Testing Machine shown in Figure 1, according to TS 2595 (1977). The capacity of Universal Testing Machine was $400 \mathrm{~N}$. The speed of testing machine was adjusted to $5 \mathrm{~mm} / \mathrm{min}$. for crashing to occur in 1 to $2 \mathrm{~min}$. Compression strength was calculated by the formula:

$\sigma_{b}=\frac{F_{\max }}{a b} N \cdot m m^{-2}$

Where, $F_{\max }$ is the breaking load on the scale $(\mathrm{N}), a$ is the crosssectional width of test sample $(\mathrm{mm}), \quad b$ is the cross-sectional thickness of the test sample $(\mathrm{mm})$.

\section{Bending strength}

The tests for bending strength were carried out with the Universal Testing Machine shown in Figure 2, according to TS 2474 (1976). The capacity of the Universal Testing Machine was $400 \mathrm{~N}$. The speed of the testing machine was adjusted to $5 \mathrm{~mm} / \mathrm{min}$ for breakage to occur in 1 to 2 min. Bending strength was calculated by the formula: 


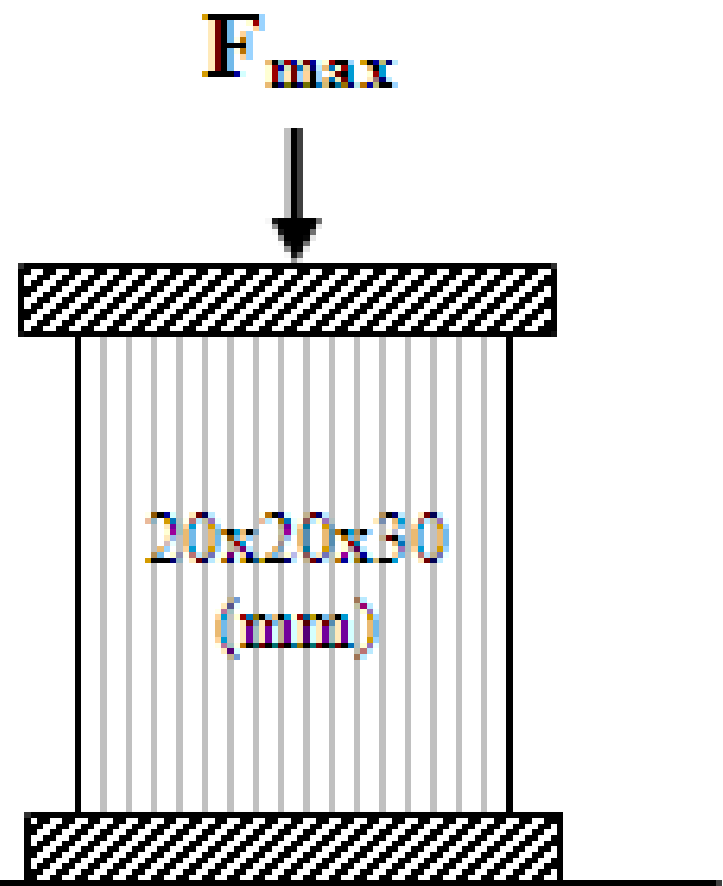

Figure 1. Universal testing machine for compression strength.

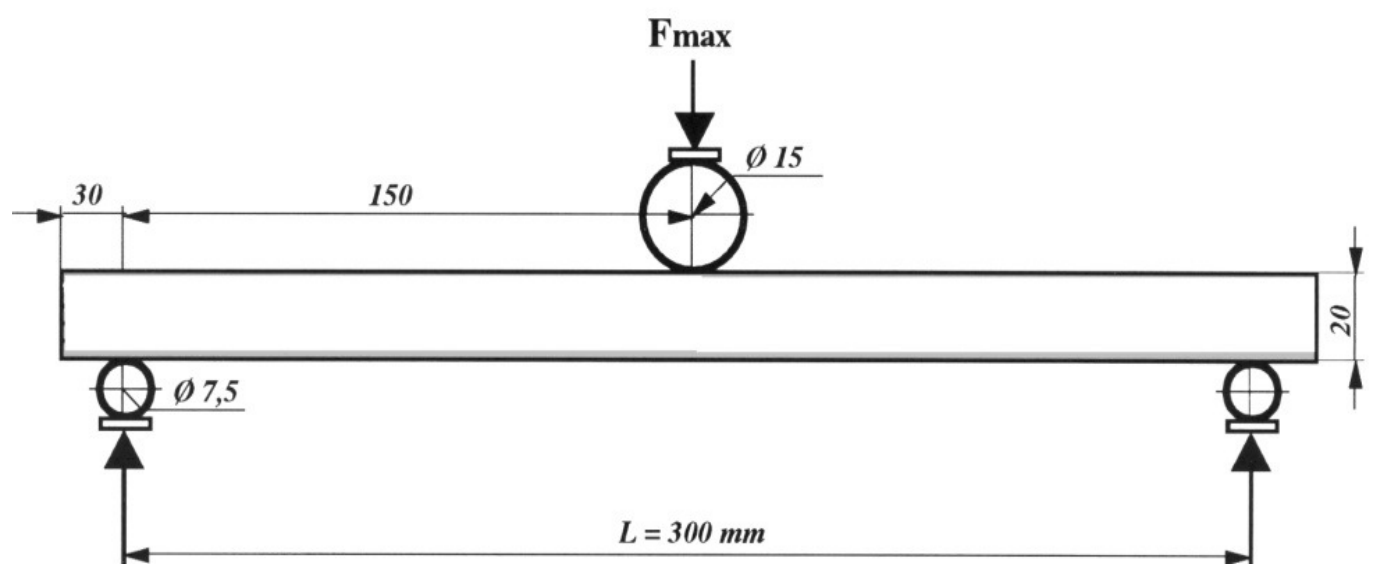

Figure 2. Test equipment for bending strength and MOE (dimensions in $\mathrm{mm}$ ).

$\sigma_{e}=\frac{3 F_{\max }\left(L-L_{1}\right)}{2 b h^{2}}\left(\mathrm{~N} \mathrm{~mm}^{-2}\right)$

Where, $F_{\max }$ is the breaking load on the scale $(\mathrm{N}), L$ is the distance between the lower tension rods $(\mathrm{mm}), L_{1}$ is the distance between two loads $(\mathrm{mm}), b$ is the cross-sectional width of test sample $(\mathrm{mm})$, and $h$ is the cross-sectional thickness of the test sample $(\mathrm{mm})$.

\section{Modulus of elasticity (MOE) in bending}

The tests for modulus of elasticity in bending were carried out with the Universal Testing Machine shown in Figure 2, according to TS 2478 (1976). The capacity of the Universal Testing Machine was
$400 \mathrm{~N}$. Deformations on the test samples were measured in the middle of the sample within a zone of five times the width of the sample by comparator. The deformations by incrementally increasing the forces were assessed with a sensitivity of $\pm 0.01 \mathrm{~mm}$. In the elastic deformation zone, modulus of elasticity was calculated by the formula:

$$
M O E=\frac{\Delta F \cdot L^{3}}{4 \cdot b \cdot h^{3} \cdot \Delta f} N m^{-2}
$$

Where, $\Delta F$ is the difference between the arithmetic average of the upper and lower limits of applied force in the elastic deformation zone $(\mathrm{N}), \Delta f$ is the net elastic deflection - difference between the measured elastic deflection in the upper and lower loading 
Table 1. Retention amounts of Rowan wood $\left(\mathrm{kg} \mathrm{m}^{-3}\right)$.

\begin{tabular}{lccccc}
\hline \multirow{2}{*}{ Statistical values } & \multicolumn{5}{c}{ Impregnation materials } \\
\cline { 2 - 6 } & $\mathbf{T e}$ & $\mathbf{l a}$ & $\mathbf{V a}$ & $\mathbf{B a}$ & $\mathbf{B x}$ \\
\hline $\mathrm{X}\left(\mathrm{kg} / \mathrm{m}^{3}\right)$ & 104.083 & 127.045 & 151.044 & 64.887 & 86.393 \\
$\mathrm{Ss}\left(\mathrm{kg} / \mathrm{m}^{3}\right)$ & 9.862 & 7.209 & 9.440 & 4.127 & 6.889 \\
$\mathrm{~V}\left(\mathrm{~s}^{2}\right)$ & 108.078 & 57.747 & 99.026 & 18.933 & 52.736 \\
$\min \left(\mathrm{kg} / \mathrm{m}^{3}\right)$ & 89.648 & 110.608 & 138.602 & 58.423 & 70.734 \\
$\max \left(\mathrm{kg} / \mathrm{m}^{3}\right)$ & 118.742 & 135.621 & 167.095 & 72.004 & 93.722 \\
$\mathrm{~N}$ & 10 & 10 & 10 & 10 & 10 \\
\hline
\end{tabular}

$\mathrm{x}$ : Arithmetic mean, v: Variance, Ss: Standard deviation, N: Number of samples, Te: Tanalith-E, la: Imersol Aqua, Va: Vacsol Azure, Ba: Boric acid, Bx: Borax.

Table 2. Variance Analysis Results of Amount of Retention (ANOVA).

\begin{tabular}{lccccc}
\hline Source of variance & Sum of squares & Degree of freedom & Mean of squares & F value & Sig. \\
\hline Between groups & 45478.129 & 4 & 11369.530 & $168.926^{\star}$ & 0.000 \\
Intra group & 3028.703 & 45 & 67.304 & & \\
Total & 48506.833 & 49 & & & \\
\hline
\end{tabular}

${ }^{*} \mathrm{P}<0.05$.

limits- $(\mathrm{mm}), L$ is the span $(\mathrm{mm}), b$ is the cross-sectional width of test sample $(\mathrm{mm}), h$ is the cross-sectional thickness of the test sample $(\mathrm{mm})$.

\section{Data analysis}

SPSS 15.0 for Windows program is used in the statistical analysis of the technological properties of the wood material tested. F-test was used to determine the differences between the technological properties of the impregnated samples. In this case, difference between the groups was significant $(\alpha=0.05)$ confidence level compared with Duncan test.

\section{RESULTS AND DISCUSSION}

\section{Retention quantities}

The amount of retention by Rowan wood according to the impregnation period is shown in Table 1. Retention amounts varied according to the type of impregnation material. The amount of retention multivariate analysis of variance of the effects of type of impregnation materials are given in Table 2.

According to the $F$ test for the quantities of wood preservatives retention, retention volumes showed statistically significant score differences according to the type of wood preservatives $(\mathrm{F}(4 ; 45)=168926, \mathrm{P}<$ 0.05 ). Duncan test results were given to determine the severity of the differences between the two groups in Table 3.

\section{Mechanical properties}

\section{Compression strength}

The statistical values of impregnated Rowan wood were given in Table 4. Compressive strength was approximately equal for all types of impregnating agents. Impregnation-treated samples gave better results than control samples. Multivariate analysis of variance on the effects of impregnation materials to compression strength was given in Table 5.

Compression strength values of Rowan wood impregnated with different agents showed statistically important differences in $\mathrm{F}$ test given in Table 5. ( $\mathrm{F}(5 ; 54)$ $=15.142, \mathrm{P}<0.05)$ Duncan test results to define the degree of importance between the groups and were given in Table 6. Compression strength was the highest with Boric acid followed by Vacsol Azure, Borax, Imersol Aqua, Tanalith-E, and control samples as shown in Figure 3.

\section{Bending strength}

Bending strength values of impregnated Rowan wood were given in Table 7. Bending strength values of Rowan wood impregnated with different impregnation materials showed statistically important differences in $\mathrm{F}$ test given in Table 8. $(F(5 ; 54)=10.404, P<0.05)$. Duncan test results to define the degree of importance between the groups and were given in Table 9. The highest bending 
Table 3. Duncan test results of amount of retention.

\begin{tabular}{|c|c|c|c|c|c|c|}
\hline \multirow{2}{*}{ Group } & \multirow{2}{*}{$\mathbf{N}$} & \multicolumn{5}{|c|}{ For sub-groups $\alpha=0.05$} \\
\hline & & $\overline{1}$ & 2 & 3 & 4 & 5 \\
\hline Boric acid & 10 & 64.887 & & & & \\
\hline Borax & 10 & & 86.393 & & & \\
\hline Tanalith-E & 10 & & & 104.083 & & \\
\hline Imersol-Aqua & 10 & & & & 127.045 & \\
\hline Vacsol Azure & 10 & & & & & 151.044 \\
\hline Significant & & 1.000 & 1.000 & 10.071 & 1.000 & 1.000 \\
\hline
\end{tabular}

Table 4. Statistical value of compression strength test.

\begin{tabular}{lcccccc}
\hline \multirow{2}{*}{ Statistical values } & \multicolumn{7}{c}{ Impregnated samples } \\
\cline { 2 - 7 } & Control & Te & la & Va & Ba & Bx \\
\hline $\mathrm{X}\left(\mathrm{N} / \mathrm{Mm}^{2}\right)$ & 53.012 & 54.622 & 55.576 & 57.829 & 61.902 & 56.244 \\
$\mathrm{Ss}\left(\mathrm{N} / \mathrm{Mm}^{2}\right)$ & 1.649 & 2.224 & 2.687 & 2.157 & 1.511 & 3.477 \\
$\mathrm{~V}\left(\mathrm{~S}^{2}\right)$ & 3.021 & 5.496 & 8.024 & 5.170 & 2.538 & 13.433 \\
$\operatorname{Min}\left(\mathrm{N} / \mathrm{Mm}^{2}\right)$ & 50.230 & 50.120 & 52.340 & 54.360 & 60.020 & 50.230 \\
$\operatorname{Max}\left(\mathrm{N} / \mathrm{Mm}^{2}\right)$ & 55.040 & 58.620 & 59.190 & 61.350 & 64.320 & 60.320 \\
$\mathrm{~N}$ & 10 & 10 & 10 & 10 & 10 & 10 \\
\hline
\end{tabular}

x: Arithmetic mean, v: Variance, Ss: Standard deviation, N: Number of samples, Te: Tanalith-E, la: Imersol Aqua, Va: Vacsol Azure, Ba: Boric acid, Bx: Borax.

Table 5. Results of compression strength variance analysis (ANOVA).

\begin{tabular}{lccccc}
\hline Source of variance & Sum of squares & Degree of freedom & Sum of squares & F value & Sig. \\
\hline Between groups & 475.544 & 5 & 95.108 & $15.142^{*}$ & 0.000 \\
Intra group & 339.169 & 54 & 6.2809 & & \\
Total & 814.714 & 59 & & & \\
\hline
\end{tabular}

${ }^{*} \mathrm{P}<0.05$.

Table 6. Duncan test results of compression test.

\begin{tabular}{lccccc}
\hline \multirow{2}{*}{ Groups } & $\mathbf{N}$ & \multicolumn{4}{c}{ For subgroups $\mathbf{\alpha}=\mathbf{0 . 0 5}$} \\
\cline { 3 - 6 } & 10 & 53.012 & $\mathbf{2}$ & $\mathbf{3}$ & $\mathbf{4}$ \\
\hline Control & 10 & 54.622 & 54.622 & \\
Tanalith E & 10 & & 55.576 & 55.576 & \\
Imersol-Aqua & 10 & & 56.244 & 56.244 & \\
Borax & 10 & & & 57.829 & \\
Vacsol Azure & 10 & & & & 61.902 \\
Boric acid & & 0.156 & 0.178 & 0.0616 & 1.000 \\
Significant & & & & & \\
\hline
\end{tabular}




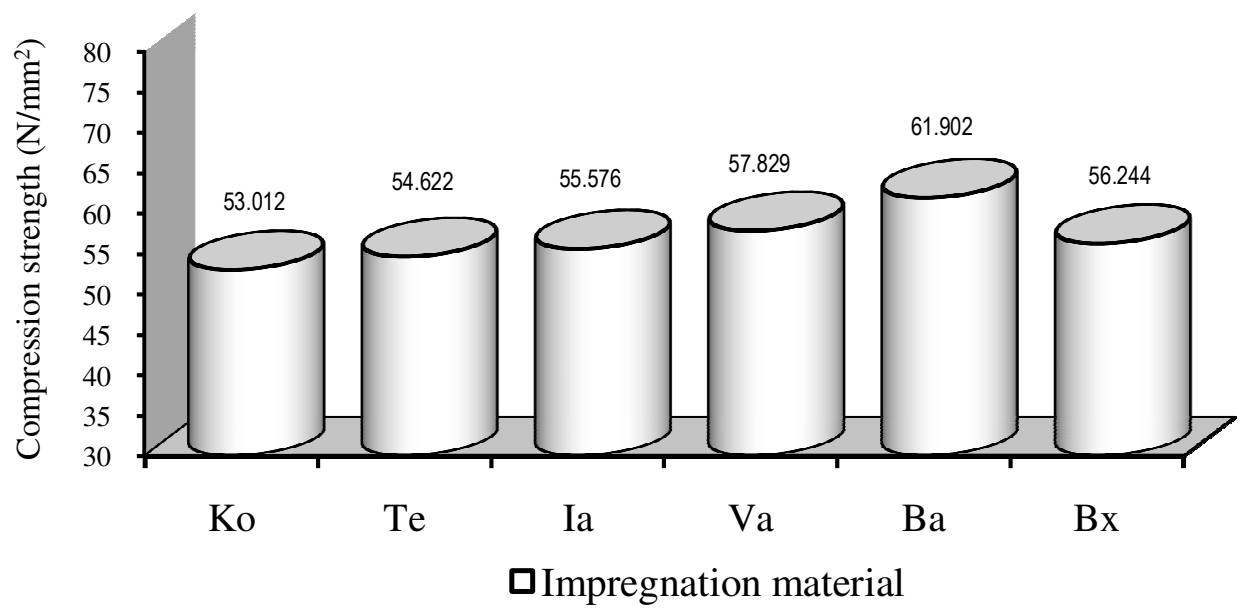

Figure 3. Compression strength for different impregnation materials.

Table 7. Statistical values of bending strength test.

\begin{tabular}{|c|c|c|c|c|c|c|}
\hline \multirow{2}{*}{ Statistical values } & \multicolumn{6}{|c|}{ Impregnated samples } \\
\hline & Co & Te & la & Va & $\mathrm{Ba}$ & Bx \\
\hline $\mathrm{x}\left(\mathrm{N} / \mathrm{Mm}^{2}\right)$ & 88.331 & 94.707 & 98.177 & 87.941 & 95.623 & 85.956 \\
\hline Ss $\left(\mathrm{N} / \mathrm{Mm}^{2}\right)$ & 4.129 & 2.813 & 6.320 & 3.773 & 5.823 & 4.059 \\
\hline $\mathrm{V}\left(\mathrm{S}^{2}\right)$ & 18.947 & 8.797 & 44.388 & 15.822 & 37.680 & 18.310 \\
\hline $\operatorname{Min}\left(\mathrm{N} / \mathrm{Mm}^{2}\right)$ & 83.033 & 90.102 & 92.356 & 80.359 & 90.234 & 80.243 \\
\hline $\operatorname{Max}\left(\mathrm{N} / \mathrm{Mm}^{2}\right)$ & 96.269 & 99.625 & 114.628 & 94.206 & 106.335 & 91.273 \\
\hline $\mathrm{N}$ & 10 & 10 & 10 & 10 & 10 & 10 \\
\hline
\end{tabular}

x: Arithmetic mean, v: Variance, Ss: Standard deviation, N: Number of samples, Te: Tanalith-E, la: Imersol Aqua, Va: Vacsol Azure, Ba: Boric acid, Bx: Borax.

Table 8. Variance analysis (ANOVA) results of bending strength test.

\begin{tabular}{|c|c|c|c|c|c|}
\hline Source of variance & Sum of squares & Degree of freedom & Sum of squares & F value & Sig. \\
\hline Between groups & 1248.024 & 5 & 249.604 & $10.404^{*}$ & 0.000 \\
\hline Intra groups & 1295.524 & 54 & 23.991 & & \\
\hline Total & 2543.549 & 59 & & & \\
\hline
\end{tabular}

${ }^{*} \mathrm{P}<0.05$.

Table 9. Duncan test results of bending strength test.

\begin{tabular}{lccc}
\hline Group & $\mathbf{N}$ & \multicolumn{2}{c}{ For sub-groups $\mathbf{\alpha}=\mathbf{0 . 0 5}$} \\
& & $\mathbf{1}$ & $\mathbf{2}$ \\
\hline Borax & 10 & 85.956 & \\
Vacsol Azure & 10 & 87.941 & \\
Control & 10 & 88.331 & \\
Tanalith E & 10 & & 94.707 \\
Boric acid & 10 & & 95.623 \\
Imersol Aqua & 10 & & 98.177 \\
Significant & & 0.312 & 0.140 \\
\hline
\end{tabular}




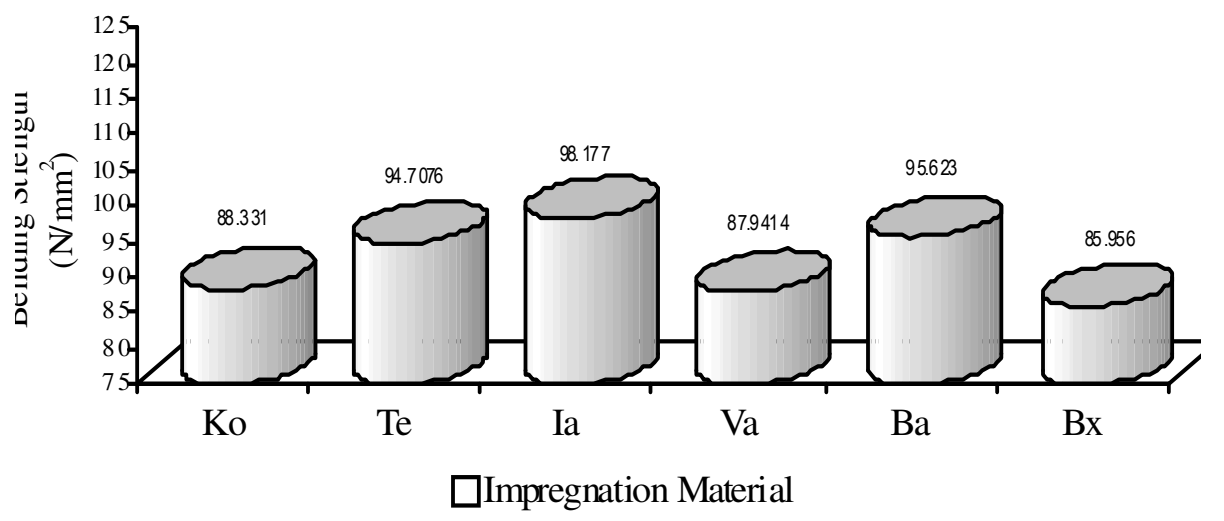

Figure 4. Bending strength values.

Table 10. Statistical values of modulus of elasticity in bending.

\begin{tabular}{lcccccc}
\hline \multirow{2}{*}{ Statistical values } & \multicolumn{5}{c}{ Impregnated samples } \\
\cline { 2 - 7 } & Co & Te & la & Va & Ba & Bx \\
\hline $\mathrm{x}\left(\mathrm{N} / \mathrm{Mm}^{2}\right)$ & 9255.810 & 10224.080 & 9853.650 & 8924.700 & 9456.480 & 9699.130 \\
$\mathrm{Ss}\left(\mathrm{N} / \mathrm{Mm}^{2}\right)$ & 226.604 & 300.203 & 340.154 & 244.804 & 309.548 & 320.627 \\
$\mathrm{~V}\left(\mathrm{~S}^{2}\right)$ & 57055 & 100135 & 128560 & 66588 & 106466 & 114224 \\
$\operatorname{Min}\left(\mathrm{N} / \mathrm{Mm}^{2}\right)$ & 9028.250 & 9800.000 & 9345.900 & 8500.000 & 9032.400 & 9284.340 \\
$\operatorname{Max}\left(\mathrm{N} / \mathrm{mm}^{2}\right)$ & 9567.200 & 10760.900 & 10442.100 & 9384.700 & 9904.310 & 10255.900 \\
\hline
\end{tabular}

$\mathrm{x}$ : Arithmetic mean, v: Variance, Ss: Standard deviation, N: Number of samples, Te: Tanalith-E, la: Imersol Aqua, Va: Vacsol Azure, Ba: Boric acid, Bx: Borax.

Table 11. Variance analysis (ANOVA) results of modulus of elasticity in bending.

\begin{tabular}{lccccc}
\hline Source of variance & Sum of squares & Degree of freedom & Sum of squares & F value & Sig \\
\hline Between groups & 10529693.840 & 5 & 2105939 & $22.050^{*}$ & 0.000 \\
Intra group & 5157279.104 & 54 & 95505.170 & & \\
Total & 15686972.940 & 59 & & & \\
\hline
\end{tabular}

${ }^{*} \mathrm{P}<0.05$.

strength was measured in Imersol Aqua, Boric acid, and Tanalith-E' followed by Borax, Vacsol Azure, and control samples. Bending strength values were given in Figure 4.

\section{Modulus of elasticity in bending}

Modulus of elasticity in bending values of impregnated Rowan wood was given in Table 10. Modulus of elasticity in bending values of Rowan wood impregnated with different impregnation materials showed statistically important differences in $F$ test $F(5 ; 54)=22.050, P<$ $0.05)$ as shown in Table 11. The highest Duncan test results was found for samples impregnated with TanalithE followed by Imersol Aqua, Borax, Boric acid, control, and Vacsol Azure (Table 12). Modulus of elasticity in bending was given in Figure 5 .

\section{RESULTS}

According to the type of impregnation materials, retention amounts showed a statistically significant difference. This may be due to different concentration of impregnation solutions. The highest value retention was obtained in Vacsol Azure followed by Imersol Aqua, Tanalith-E, Borax, and boric. According to the type of impregnation material, the highest retention amounts were in Vacsol Azure samples $\left(151044 \mathrm{~kg} / \mathrm{m}^{3}\right.$ ) followed by Imersol-Aqua $\left(127045 \mathrm{~kg} / \mathrm{m}^{3}\right)$, Tanalith-E $\left(104083 \mathrm{~kg} / \mathrm{m}^{3}\right)$, Borax $(86$ $\left.393 \mathrm{~kg} / \mathrm{m}^{3}\right)$, and Boric acid $\left(64887 \mathrm{~kg} / \mathrm{m}^{3}\right)$. The amount of retention in samples impregnated with Vacsol Azure is higher due to the difference in concentration between the impregnation materials. High amount of retention of samples impregnated with Vacsol Azure was possibly due to the high retention ability of it. 
Table 12. Duncan test result of modulus of elasticity in bending.

\begin{tabular}{|c|c|c|c|c|c|c|}
\hline \multirow{2}{*}{ Groups } & \multirow{2}{*}{$\mathbf{N}$} & \multicolumn{5}{|c|}{ For Sub-groups $\alpha=0.05$} \\
\hline & & 1 & 2 & 3 & 4 & 5 \\
\hline $\mathrm{Va}$ & 10 & 8924.701 & & & & \\
\hline Ko & 10 & & 9255.807 & & & \\
\hline $\mathrm{Ba}$ & 10 & & 9456.488 & 9456.488 & & \\
\hline $\mathrm{Bx}$ & 10 & & & 9699.131 & 9699.130 & \\
\hline la & 10 & & & & 9853.657 & \\
\hline $\mathrm{Te}$ & 10 & & & & & 10224.080 \\
\hline & & 1.000 & 0.152 & 0.084 & 0.268 & 1.000 \\
\hline
\end{tabular}

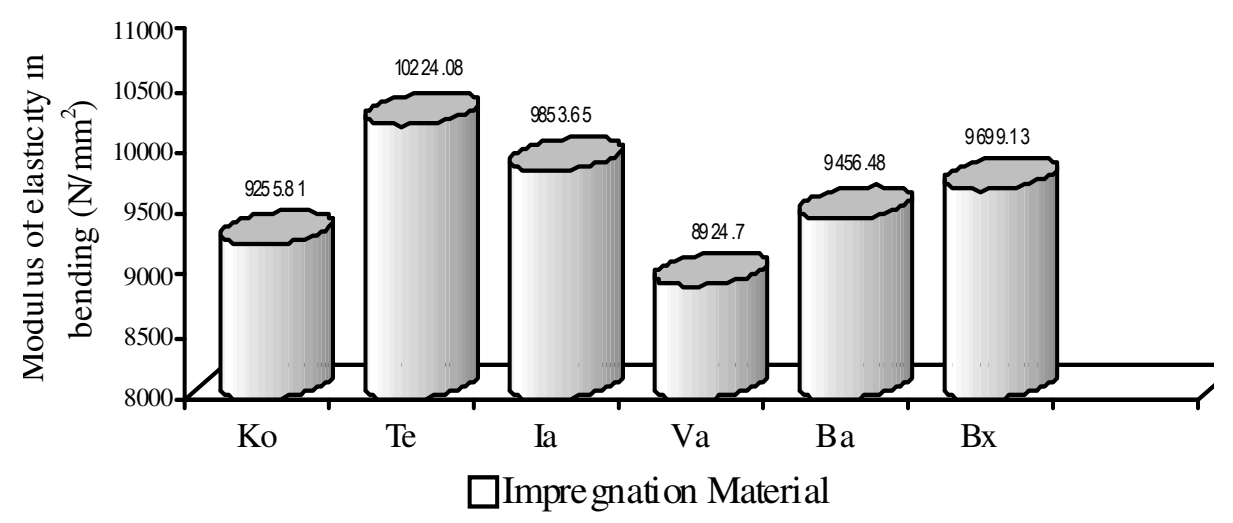

Figure 5. Modulus of elasticity in bending.

Compression strength was highest in Boric acid $\left(61.902 \mathrm{~N} / \mathrm{mm}^{2}\right)$ followed by Vacsol Azure (57.829 $\mathrm{N} / \mathrm{mm}^{2}$ ), Borax $\left(56.244 \mathrm{~N} / \mathrm{mm}^{2}\right.$ ), Imersol Aqua (55.576 $\left.\mathrm{N} / \mathrm{mm}^{2}\right)$, Tanalith-E $\left(54.622 \mathrm{~N} / \mathrm{mm}^{2}\right.$ ) and control sample $\left(53.012 \mathrm{~N} / \mathrm{mm}^{2}\right)$. The difference between Imersol Aqua, Borax, and Vacsol Azure was not found statistically meaningful. Impregnation material did not decrease the compression strength. So, those materials may be used in construction sector.

Bending strength of impregnated materials were found as Imersol Aqua $98.177 \mathrm{~N} / \mathrm{mm}^{2}$, Boric acid 95.623 $\mathrm{N} / \mathrm{mm}^{2}$, Tanalith-E $94.708 \mathrm{~N} / \mathrm{mm}^{2}$, control $88.331 \mathrm{~N} / \mathrm{mm}^{2}$, Vacsol Azure $87.941 \quad 116,230 \mathrm{~N} / \mathrm{mm}^{2}$ and Borax 85.926 $\mathrm{N} / \mathrm{mm}^{2}$. According to $F$ test, bending strength showed statistically important differences $(F(5 ; 54)=10.404, P<$ 0.05). According to Duncan Test results, the highest bending strength was in Imersol Aqua, Boric acid and Tanalith-E followed by Borax, Vacsol Azure. The reason for lower value in samples impregnated with boron compounds may be due to its acidic property.

Modulus of elasticity in bending was measured as follows; Tanalith-E $102.240 \mathrm{~N} / \mathrm{mm}^{2}$, Imersol Aqua $9853.700 \mathrm{~N} / \mathrm{mm}^{2}$, Borax $9699.130 \mathrm{~N} / \mathrm{mm}^{2}$, Boric acid $9456.480 \mathrm{~N} / \mathrm{mm}^{2}$, control $9255.800 \mathrm{~N} / \mathrm{mm}^{2}$, and Vacsol
Azure $8924.700 \mathrm{~N} / \mathrm{mm}^{2}$. According to $\mathrm{F}$ test, modulus of elasticity in bending of impregnated samples was found significant $(F(5 ; 540)=22, P<0.05)$. According to Duncan test, the highest modulus of elasticity was in Tanalith-E followed by Imersol Aqua, Borax, Boric acid, and Vacsol Azure

As a result, the highest values in compression strength of Rowan wood was measured in samples impregnated with Boric acid, in bending strength impregnated with Imersol Aqua and in modulus of elasticity in bending impregnated with Tanalith. The lowest values were with Tanalith-E in compression strength, with Borax in bending strength, with Vacsol Azure in the modulus of elasticity in bending. According to this results Rowan wood may be impregnated with Tanalith- $E$ to be used in the fields where compression strength, bending strength, and modulus of elasticity in bending are critical.

In general the results of this study on the mechanical properties of Rowan wood impregnated with various impregnation materials are compatible with the findings in literature on the effect of various impregnation materials on mechanical properties of different tree species.

Togay (2009) found that except for oak samples, one time impregnation with timbercare aqua due to the 
increasing MOE and impregnation with timbercare aqua can be useful for the wood material subject to bending stress, which needs high elasticity.

\section{ACKNOWLEDGEMENTS}

This study is a part of M.Sc. Thesis prepared by Neslihan SÜZER ERTÜRK, Institute of Science and Technology, Gazi University, Ankara, Turkey.

\section{REFERENCES}

ASTM-D 1413-76 (1976). Standard Test Method of Testing Wood Preservatives by Laboratory Soilblock Cultures. Ann. Book ASTM Stand. pp. 452-460.

Aytaşkin A (2009). Some technological properties of wood imptegnated with various chemical substances. M. Sc. Thesis, Karabük University Graduate School of Natural and Applied Sciences Department of Furniture and Decoration Education, Karabük. P. 134.

Bendtsen BA (1984). Mechanical Properties of Longleaf Pine Treated Waterborn Salt Preservatives, USDA Forest Service. USA. P. 434.

Evans PD, Michell AJ, Schmalzl K (1992). Studies of the Degradetion and Protection of Wood Surfaces. Wood Sci. Technol. 26:151-163.

Gillwald W (1961). Der Einfluss Verschiedener Impragnier Mittel Auf Die Physikallischen Und Festigkeitseigen Schaften Des Holzes. Holtechnologie 2:4-16.

Hickson's Timber Impregnation Co.(GB) (2000). Into the $21^{\text {st }}$. Century, Imersol-Aqua Brochure, Datassheet, 6214, 1-4, Hickson Timber Treatments.

Isaacs CP (1972). The Effect of Two Accerelated Treating Methods on Wood Strength. AWPA, USA. 68:175-182.

Kartal SN (1998). The Biological Resistance, Leachability and Strength Properties of Wood Treated with CCA and CCB Preservatives, Ph. D. Thesis, Istanbul University Instit. Sci. Istanbul. P. 157.

Kollmann F (1959). Die Eigenschaftanderung Von Gruben Holz Nach Schutzsalzimprag-nierung, Forschungsber, Des Landes Nordhrhein, Westfalen-Germany.

Korkut S, Guller B, Aytin A, Kök MS (2009). Turkey's native wood species: Physical and mechanical characterization and surface roughness of Rowan (Sorbus aucuparia L.). Wood Res. 54(2):19-30.

Lutomsky K (1976). Effect of Treatment Conditions Using The Hot-Cold Method of Impregnation Pine Wood with Water Solution of Static Bending of Treated Wood, Zest. Probl. Nauk. Rolniczych. P. 178.

Özçifci A, Atar M, Uysal B (1999). The Effects of Wood Bleaching Chemicals on The Surface Gloss and the Adhesion Strength of Varnishes. Turk. J. Agric. For. 23(EK3):763-770.
Richardson BA (1987). Wood Preservation, The Construction Press: Lancaster. England.

Stabnikov VM (1957). Puti Uviliczenia Sroka Sluschby Dreviesinyw Konstrukcjach. Leningrad. pp. 81-185.

Togay A (2009). Effect of Impregnation with Timbercare Aqua on the Properties of Some Woods. J. Appl. Sci. 9(5):956-961.

TS 2470 (1976). Wood - Sampling Methods and General Requirements for Physical and Mechanical Tests. Türk Standartlari Enstitüsü. Ankara.

TS 2471 (1976). Wood, Determination of Moisture Content for Physical and Mechanical Tests, TSE, Ankara.

TS 2472 (1976). Wood - Determination of Density for Physical and Mechanical Tests, TSE, Ankara.

TS 2474 (1976). Wood - Determination of Ultimate Strength in Static Bending. TSE. Ankara.

TS 2478 (1976). Wood-Determination of Modulus of Elasticity In Static Bending. TSE. Ankara.

TS 2595 (1977). Wood-Determination of Ultimate Stress In Compression Parallel to Grain. TSE, Ankara.

TS 344 (2012). Wood preservation-General Rules. TSE. Ankara.

TS 345 (2012). Testing methods for the effects of wood imregnating substances, TSE, Ankara.

TS 4176 (1984). Wood - Sampling Sample Trees and Long for Determination of Physical and Mechanical Properties of Wood in Homogeneous Stands. T.S.E. Ankara.

TS 53 (1981). Wood - Sampling and test methods - Determination of physical properties. T.S.E. Ankara.

Uysal B, Atar M, Özçifci A (1999). The Effects of Wood Bleaching Chemicals on the Bending Strength of Wood. Turk. J. Agric. For. 23(6):615-620.

Vologdin AJ (1966). Vlijanije Rozlicznych Antiseptic of Na Fizyko Mechanitchiestkije Svosjstva Dreviesiny Sosny Svotsva Dreviesin, Jejo Zaschita; Novyje Dreviesinyje Materialy. Moskova.

Wazny J (1973). Investigations of The Influence of Wood Preservatives on Strength, Dreviesiny, Sreda. 3:181-185. 